\title{
Exploring the constructivist mentoring program in developing EFL teacher professionalism: A qualitative approach
}

\author{
Kurniawan Yudhi Nugroho ${ }^{1 *}$, Zulfa Sakhiyya ${ }^{2}$, Mursid Saleh ${ }^{2}$, Januarius Mujiyantoº $^{2}$, \\ and Dwi Rukmini ${ }^{2}$ \\ ${ }^{1,2}$ Doctoral Degree Program of English Language Education, Postgraduate Studies, Universitas Negeri \\ Semarang Gedung A, Kampus Paska Sarjana, Jl. Kelud Utara III, Semarang, Central Java, Indonesia \\ ${ }^{1}$ English Teacher Education Study Program, Faculty of Language and Communication Science, Universitas \\ Islam Sultan Agung, Jl. Raya Kaligawe Km. 4 Semarang, Central Java, Indonesia
}

\begin{abstract}
This paper investigates the implementation of constructivist learning, as it was practiced by five EFL teachers at a vocational high school in Indonesia. We offer a 'mentoring program' for teachers to support each other and provide resources that are bottom-up, free, and relevant, conducted in a collegial atm4osphere. We adopted a qualitative approach as it enabled us to understand and cultivate deeper the learning process that occurred in the classroom. Data were qualitatively collected and analyzed in two ways. First, it focused on the participants' interview, observation, self-reflection and discussion on the variables in the mentoring program covering the need and expectation of EFL teachers in the formal pedagogical setting, sources of teachers' resistance to participate in Teacher Professional Development (TPD) program, the impact of TPD program on the teacher pedagogical competence, and conditions contributing to sustainable development as a result in the TPD program. Second, it was to disclose the researchers' viewpoints and reflections under variables, as stated in the earlier analysis. Our research findings suggested that constructivist-learning practices were proven to be successful in helping the teachers experienced promising mentoring progress of TPD. Teachers and students underwent a significant change as the learning activities became more engaging and fun. Teachers confessed to have their pedagogical knowledge and practice expanded while having their attitude and mindset shifted after going through a series of activities inside the mentoring program. The program was central in nurturing teachers' self-identity and helping them overcome their internal blocks. In the longer-term, this program contributes to developing teacher professionalism as they started to see the potentials and positives impacts of TPD programs.
\end{abstract}

Keywords: Constructivist learning theory; educational action research; EFL teacher professionalism; mentoring program; qualitative approach

\section{First Received:}

14 January 2020

Final Proof Received:

24 May 2020
Revised:

13 March 2020

How to cite (in APA style):

Nugroho, K. Y., Sakhiyya, Z., Saleh, M., Mujiyanto, J., \& Rukmini, D. (2020). Exploring the constructivist mentoring program in developing EFL teacher professionalism: A qualitative approach. Indonesian Journal of Applied Linguistics, 10(1), 132-142. https://doi.org/10.17509/ijal.v10i1.25021

\section{INTRODUCTION}

Disruptive era has brought radical impacts to the system of education worldwide. Teachers and other educational stakeholders are required to fast adapt to the situation. Teacher professional development, as a

\footnotetext{
* Corresponding Author

Email: kurniawan@unissula.ac.id
} 
space to develop teachers' competence and performance, is central in connecting teachers' existing professional-quality with the current demand of the teaching. Therefore, teacher professionalism and professional development issues (hereinafter, TPD) are not trivial. Teacher professionalism is greatly influenced by functions, status, quality, and teachers' work (Richards \& Schmidt, 2010). It is "an occupation that performs an important social function based upon a high degree of skill. The work and practice involved are not dependent upon routine behaviors, rather on a systematic body of theory and knowledge learned through education and training." (p. 463). Therefore, teacher professionalism has to regard teachers' level of knowledge, responsibility, and autonomy (Jensvoll \& Lekang, 2018). To operationalize the study, the existing term of teacher professionalism is further elaborated by involving the concept of professionalism as stated in the regulation of the minister of Indonesia national education number 16, year 2007 on academic qualification standard and teacher competences. While the issues of teacher professional development practices are discussed in the latter part of the paper.

Indonesian teachers are often encountered with a dilemma in carrying out duties. On the one hand they have to provide students with adequate support to learning within a formal education setting; on the other hand, they are faced with contextual problems as the impacts of the education system. They have to strive themselves both in the capacity as individuals and as professionals (Kiilo \& Kutsar, 2012). Arising from this, the most likely solution to develop the teachers' current professional performance is to get them involved in professional development activities. Although it is realized, the practices do not consistently guarantee a promising success of teacher development. Professional development issue is unique and complex as it is "not well structured" (Dayoub \& Bashiruddin, 2012), the practices successful in a particular setting, will likely be hard to result in the same outcome when it is applied to another different context of professional development practices (Opfer \& Pedder, 2010). It implies that factors affecting TPD practices are varied. Some studies have come up with notions related factors affecting the TPD, yet the salient and generalizable factors which affect teacher development remain unclear, the common assumption to understand is that learning is affected by personal and contextual factors (Clardy, 2000; Kiilo \& Kutsar, 2012; Kwakman, 2003). To refine the factors, the theory of adult learning suggests participation (Nelson, 2017), while other theories argue active involvement in learning opportunities (Jones \& Brader-araje, 2002; Perkins, 1999) and collaborative and collegial environment (Knapp, 2003; Putnam \& Borko, 2000) as well as commitment (Tanang \& Abu, 2014; Thornton \& Cherrington, 2019) and reflection (Gleeson \& Davison, 2016;
Richards, 1990) as the factors to influence teacher development.

Departing from the issue of professional development and having been inspired by the factors, complexity theories (Mason, 2008a, 2008b) and existing researches in complexity (Cohen \& Grossman, 2016; Hetherington, 2013; Rahman, 2016), constructivist learning theory was adopted to design intervention for the teacher professional development for EFL educators in a vocational high school in Indonesia. This six-month mentoring program was conducted in collaboration with researchers from the university through the design of a qualitative approach exposing the constructivist learning theory and educational action research (hereinafter called qualitative approach) to accommodate the need for teachers' professional development. Constructivist learning theory was selected as it encourages active and constructive process of learning for knowing and understanding (Jones \& Brader-araje, 2002; Nugroho \& Wulandari, 2017; Perkins, 1999). Knowledge is inside of learners and it can be further flourished through receiving as many inputs as possible through experiencing meaningful social practices involving the processes of learning (Packer \& Goicoechea, 2010), for example, an interaction where reflection, communication skill development, exposure towards various ideas and deep conceptual understanding as well as collaborative knowledge construction, are accommodated to inductively construct personal understanding (Ashton-Hay, 2006; Gleeson \& Davison, 2016; Park \& So, 2014). Whilst, educational action research in the present research was chosen because it offers the concept where teachers can accept confusion and disorientation while evolving a more comprehensive understanding in the field they focus to learn for their future professional practices as a researcher and practitioners (Angelides et al., 2005; Duenkel \& Pratt, 2013; Mcniff \& Whitehead, 2006). Besides, it brings theories, and practices together through experience (Hodgson et al., 2013).

Foregoing work on professional development for English Language teachers has defined the growing literature on English language teacher professional development focusing on various dimensions. One strand of studies has centered on the common issues affected English language teacher professionalism and professional development from the teachers' viewpoints (Avillanova \& Kuswandono, 2019; Bharati, 2010; Francofuenmayor et al., 2015; Wichadee, 2012; Yuwono \& Harbon, 2010). While another study suggested several issues affecting the English language teacher professionalism from the perspective of the institution (Ferhat, 2016). Likewise, some studies came up to enrich the findings by presenting different foci of investigation, for example, the teachers' perception on the use of technology, pedagogy and 
content knowledge for teacher professional development (Alhabahba \& Mahfoodh, 2016; Drajati et al., 2018); the impact of the training projects on English language teacher professional development (Banegas et al., 2013; Borg et al., 2018); the influence of the school context on teachers' engagement in learning activities (Canh \& Minh, 2012); the impact of experiential learning for teacher professional development (Girvan et al., 2016; Yazan \& Peercy, 2018); the connection between professional development practice and teachers' leadership (Hansen-Thomas et al., 2014); the identification of information and suggestion as a way to better improve the teacher developmental program (Sulistiyo, 2015; Zein, 2016), and the performance assessment for teacher professional development (Tigert et al., 2018).

Although studies on English language teacher professional development have been growing in numbers, more researches are still required to continuously verify the contribution of professional development practices to English language teacher development. This paper presented a qualitative research study which explored the use of constructivist learning theory and the educational action research to examine how the constructivist mentoring program developed the EFL teacher professionalism in meaningful ways to the level they needed to mingle with the contextual issues within the formal education system at their institution. Previous studies in English language teacher training and education claimed teacher professional development as an integral part of teacher professionalism, while some other relevant studies showed interrelationship between professional development practices and teacher performance in carrying out their professional duties (Banegas et al., 2013; Borg et al., 2018; Novozhenina \& López, 2018; Roux \& Valladares, 2014). The lesser-known is how teacher professional development practices should be organized to provoke the development of teachers' existing knowledge and competences, specifically associated with professional, pedagogical, social, and personality matters. Therefore, this present study aims to elucidate the way learning experience affected EFL teacher professional development during the formative and transitional period of their professional learning. Likewise, this study was to enrich the previous findings on English language teacher professional development through exploring the following question: How does the constructivist mentoring program develop the EFL teacher professionalism?

\section{METHOD}

This study employed constructivist learning theory and the educational action research developed by Mcniff \& Whitehead (2006) to the design of the intervention. The steps of the action research included the process of reviewing current practice; identifying aspects to improve; imagining a way forward; trying it out; taking stock of what happened; modifying plan in the light of what had been found and continued with 'action'; monitoring what was done; evaluating the modified action; evaluating the validity of the account of learning; and developing new practices in the light of the evaluation. These steps would spin up repeatedly until the objectives were achieved.

This study was participated by five EFL teachers, two males and three females teaching English subject at a vocational high school in Central Java, Indonesia. To begin the study, the initial processes in the action research (review and identification) were conducted after data were sufficiently collected from the research participants through interview and observation. Completed with the earlier steps, the research team proceeded with designing a model for the mentoring program before inviting the previously observed participants to join a workshop as designed. This workshop was created to help the participants resolve their problems according to pedagogy and to equip them with knowledge of constructive teaching. The workshop also facilitated the participants with the knowledge and practices of becoming a mentor and mentee required during the mentoring period. In another chance, the participants were also trained to use different kinds of evaluation forms to record their pedagogical performances. Having done with the earlier steps, the participants were set to critically review and re-discuss their recent vision, aims, and objectives of teaching before designing action plans for their entire mentoring period. Action plans they created would periodically be evaluated and updated based on the results in the reflection procedures. All processes in the mentoring program would be deeply evaluated and developed by following the constructivist learning theory and the action research steps (Mcniff \& Whitehead, 2006).

The participants together with their students in the classroom would execute the plans. The actions performed in the plans would be observed and recorded regularly by the practicing teachers and by the appointed partner as scheduled. Figure 1 depicts the design of collaborative observation among the participants.

Each participant would alternately get the turn to observe and be observed and to record and be recorded the participants' performance. The results from the observation and recording were used as an input for planning the next step of the mentoring program. These actions were repeatedly executed until the result met the expectation. With this evidence, appreciative inquiry and threshold concept were introduced. Appreciative inquiry is a method used to help participants delve, take benefit from past incidents, visualize the future, and plan effective processes and ways to achieve the goals. 
Appreciative inquiry in the project was set through dialogue and interaction between the researchers and the participants where it involved questioning, positively commenting, and promoting a supportive environment for the participants (Kiilo \& Kutsar, 2012). While threshold concept was introduced to help ease the process of learning and fill the gaps that resulted in the appreciative inquiry. This step was made through evaluating the previous actions (Meyer \& Land, 2005). By counting in these concepts, both the participants and the researchers would benefit from developing reflection.

Figure 1

The Design of Collaborative Observation

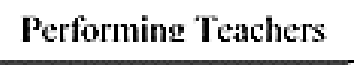

Observing Teachers

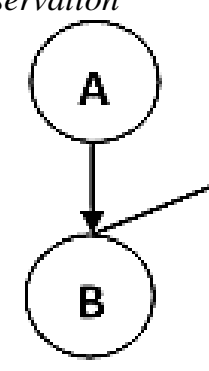

Constructivist learning practices referred to how the performing participants made meaning to an interaction between experiences and ideas without having too much intervention from the researchers. The roles of the researchers were not dominant and limited at creating the general concept of the mentoring program, doing supervision and training for the participants. The researchers did not go for pedagogical intervention. Nevertheless, they mediated the monthly discussion among the participants based on the principles of appreciative inquiry and the threshold concept as explained earlier to revise and plan for the upcoming pedagogical activities. In addition, they encouraged meaningful interaction among the participants and helped sustain their motivation through sharing and discussion. This was a forum for all members to learn together through dialogue, sharing, and discussion related specifically to pedagogical issues. In addition to the activities, the participants also evaluated their teaching performance every time they finished practicing. This evaluation was conducted through filling out the predesigned teacher self-evaluation form comprising the aspect such as context/ goal setting, student assessment, attention to individuals, instructional practices and classroom routines, positive and supportive learning environment, quality of lessons, preparation and response to learners' needs, and evidence of differentiation (Strategic Research, n.d.).

Data of the present study were qualitatively collected through observation, interview, participants' self-evaluation report, and monthly discussion. The research instruments such as, fieldnotes in the observation, questions in interview and discussion, reflective questions in the selfevaluation forms were employed and developed in accordance with the research objectives. To ensure clarity and comprehensiveness of those instruments, colleagues who were non-member of the study were involved to review each item in the instruments by referring to the observation, interview and document checklists adapted from Creswell, (2012). To guarantee a quality discussion, three components, such as limitations, systematic questions and criteria for evaluating solution, were involved to make the discussion processes clear and logical to the participants (Galanes \& Adams, 2019; Krueger, 2002). The observation and discussion sessions were all recorded and transcribed for the benefit of the study. To answer the central question related to how the constructivist mentoring program developed the EFL teacher professionalism in meaningful ways to the level they needed to mingle with the contextual issues within the formal education system at their institution, the research data were qualitatively analyzed through discourse analysis strategy (Wildemuth \& Perryman, 2009).

\section{FINDINGS AND DISCUSSIONS}

The following section presents the findings and discussions from the observation, interview, participants' self-evaluation reports as well as monthly discussion. The findings and discussion are presented into five main issues related to the research question: How does the constructivist mentoring program develop the EFL teacher professionalism?. The first theme examines the need and expectation of EFL teachers in a formal pedagogical setting. The second theme explores the sources of teachers' resistance to participate in TPD program, and the third theme investigates the impact of TPD program on the teacher pedagogical competence, whilst, the fourth theme discusses the conditions heading to the sustainability of change as a result in the TPD program.

\section{The need and expectation of EFL teachers in a formal pedagogical setting}

This research had revealed several contextual issues connected to the need and expectation of EFL teachers according to a formal pedagogical setting. In 
the early interview about the perspective of teaching, the participant (whose name was in pseudonym) valued teaching as a challenging job which required professionalism to perform duties (Boud \& Hager, 2012; Namunga, N.W., \& Otunga, 2012). Another participant argued teacher professionalism was central to help learners develop their potentials to the level they should be. Whilst, the rests of the participants suggested that teacher professionalism was not only about knowledge mastery, associated with professional competence, but also connected with the other three competencies such as social, pedagogical, and personality competences. This argument at the same time confirmed the participants' awareness of recently applied regulation concerning teachers, lecturers, and related matters (See, The Law of the Republic of Indonesia Number 74 Year 2008; The Law of the Republic of Indonesia Number 14 of 2005; The Regulation of Minister of National Education Number 16 Year 2007). Despite having been teaching for many years, all participants explained that applying the desired concept of professionalism as a whole in teaching was not easy. They further argued the concepts would better be used to support their professional practices, unless they were sufficiently trained. This finding helped infer that the teachers still required developmental activities to improve their existing skills and knowledge, mainly related to the four competencies as stipulated in the government regulations, even though they had long teaching experience. Professional development helps teachers improve their professional quality, specifically to fulfill their roles as an educator (Kennedy, 2016; Wardoyo et al., 2017). Therefore, continuously developing teachers' service performance quality was considered important (Yuwono, \& Harbon, 2010).

In addition, the observation and other interview stages had portrayed potential cases to discourage the classroom learning activities such as Context (less technical learning goals, where the teachers found it difficult to implement); Student assessment (assessing instruments were available with critiques. The instruments were not standardized and lack of exposure to the learning objectives. Most importantly, these instruments were very rarely examined for its effectiveness); Attention to individuals (Interactions mostly focused on the active students. The silent students were once checked, but their issues of learning were delved incomprehensively for improvement); Instructional practices, (The teachers were the center for learning); positive and supportive learning environment did not promisingly appear in the classroom. The class structure did not sufficiently provide students with diverse chances of learning which allowed them to experience success (Lower competence students received insufficient options to select questions fitted to their existing background of knowledge. Therefore, some perceived to be mentally in-secured and found it hard to see the classroom as a place where they could freely express ideas without being afraid of negative judgment); Teaching Preparation, (All issues as mentioned were truly rooted from the way the teachers prepared the lessons); and response to the students' need, (there were gaps in practices between students' existing knowledge and their learning contents). Adding to those seven issues, less comfortable classroom physical setting (For example, densely populated classroom; and hardly portable learning properties such as wooden tables and chairs) and low English performance of English teacher (repeated mistakes in grammar and pronunciation) were regarded as the other potential cases to decrease the quality of learning processes. With reference to the research objective, the findings were categorized as the needs for teacher development and used as the references for the activity development within the mentoring program.

Findings in the early observation indicated that realities in the practices did not always go as planned, although teachers might have done best to prepare the lesson. What teachers believed to be applicable in the past was not necessarily in accordance with the condition in the future. The situation implicitly explains that knowledge is inconsistent and conjectural (Creswell, 2009). Development of knowledge literally affects how the knowledge should be distributed, as the result, teacher professionalism needs to be continuously updated. In accordance with participants' response, it is unfortunate, the recent trend of professional development programs offered to them mostly adopt top-down approaches rather bottom-up (For example seminar, training, and workshop). Professional development activities, adopting top-down approaches, are generally less applicable to the situation the teachers face in the classroom (Roux \& Valladares, 2014). As a result, lessons learned from the program become irrelevant and potentially get the teachers back to the old routines. Therefore, some proponents of constructivist learning theory suggested that the design of the professional development practices regards the teachers' existing knowledge as the point where teacher professionalism can be further flourished (Angelides et al., 2005; Kiilo \& Kutsar, 2012). Likewise, it is essential to identify central problems to empower the existing concept of teacher professional development (Kennedy, 2016). The central aim of constructivist learning is geared towards providing learners with a meaningful experience of learning (Jones \& Braderaraje, 2002; Perkins, 1999) and encouraging learners' involvement in an active and constructive process of knowing and understanding (Nugroho \& Wulandari, 2017; Perkins, 1999; Zuber-skerritt \& Roche, 2014). To better empower the intervention, the participants and the program designers (researchers) engaged in the practices should start to collaboratively think from the critical viewpoints by counting in the 
existing knowledge and previous experience to explore the need for development. For example, while reflecting, the participants and the program designers are capable of concluding why things happened as they did. Therefore, reflection should be more than just summarizing what happens in the classroom. This process of the reflection lets both the participants and the program designers to recall, consider and evaluate previous experience for improving future practices (Richards, 1990). The first theme in the early data collection processes has discussed the need and expectation of EFL teachers according to a formal pedagogical setting. The following theme explores the sources of teachers' resistance to participate in the TPD program.

\section{The sources of teachers' resistance to participate in TPD program}

Although the teachers encountered numerous issues related to the pedagogical performance, they were hardly involved in the professional development activities. Responding to the interview, the participants articulated to have low support from the institution, mainly to the policies, including finance which was available but in a very limited amount, as a result, teachers' participation in professional development programs was alternately conducted among the teachers at the institution. Many teachers rather waited for the turn, but the rest sometimes voluntarily participated in the programs as they realized the benefit, although they had to personally bear the financial consequences. From the interview, bearing the cost for the TPD program most of the time would finally become such a distinctive issue for them. The finding implies that financial support is truly essential to encourage teacher professional development. The financial support geared towards both developing TPD program, and giving appropriate incentives for the participants may likely enhance better teaching improvement, professional development participation and collaboration among teachers, specifically to new teachers (Mitchell \& Peters, 1988; Zhang et al., 2019). While discussing the issues of finance, policies related to TPD implementation have to be set to value effectiveness, efficiency, and compliance of the policy, in addition to upholding social justice, fairness, and equality to promote a promising success of the program (Kennedy, 2007). Policymakers which are not well equipped with rooted information would only be able to set general agreement, which cannot effectively support the activities (Purdon, 2004). Therefore, this qualitative research was conducted to help reveal potential factors according to teachers' resistance to participate in the TPD program.

Other than the financial and the policies support for professional development implementation, the different participants explained, taking a part in the recently offered programs of TPD by external agencies such as workshop, training, and seminar, did not mean a lot, they found the knowledge they brought to the classroom from the programs did not truly fit the context they faced in the field as the result they went back to the old ways of teaching. Earlier studies regard the TPD program adopting a top down approach is generally less applicable to the situation the teachers face in the classroom and so it should consider the bottom up model as the approach to design TPD practices (Drajati et al., 2018; Roux \& Valladares, 2014).

Apart from the earlier issues, the load of administrative works where the participants perceived to be time and energy-consuming became another source of the resistance. For this reason, some teachers said to have been doing a lot of duties, and so, professional development activities were executed if they could and were available, in terms of supports from the institution. This finding explains, time can be another factor to influence the teacher's unwillingness to attend the TPD program (Good, 2003; Zhang et al., 2019). Therefore, the political will from the institution had a strategic role to promote teacher participation in the TPD program. Although a particular institutional policy is essentially important to support conduct the teacher professional developments, a previous study indicates that the policy is not the only factor to affect, other initiatives may likely be taking apart as another success source of the practices. Therefore, the implication of evaluation results between educational initiatives and TPD policies is not to be separated (Purdon, 2004).

To enrich the findings in the subsection, the data collection result also informed that teachers' awareness to develop was still low. In a very narrow sense, collaborative works among teachers did not appear to be effectively and intensively conducted (e.g. collaborative research and discussion). Although experiencing several time research trainings, teachers did not show a thorough understanding of doing a research and a promising discussion. The participants admitted that culturally people were not ready for critiques and suggestions, and some were admitted to have low motivation in reading and to experience new pedagogical methods. To end this section, lack of supports from institution potentially demotivate teachers from doing TPD, which eventually endanger the process of education (Zhang et al., 2019).

\section{The impact of TPD program on the teacher pedagogical competence}

The six-month mentoring program was held to follow up the findings as presented in the first section of this finding and discussion. These findings were the beginning step to formulate a program for the mentoring participants. To succeed the program, relevant stakeholders were involved. This involvement allowed them to closely see issues faced by teachers from different perspectives. Likewise, it was to create appropriate planning of activities to 
better support teacher development (Good, 2003). Stakeholders' involvement in the program has better potentials to encourage meaningful practices of teacher development (p.14). From the result of the interview, the participants explained, the activities in the program had promoted not only the development of their pedagogical practices but also positive encouragement to changes in the attitude and mindset. In addition, they further elaborated that their confidence was improved as they started to apply various teaching strategies. They admitted teaching turned into pleasant activities, although realizing numerous issues occurred in the process. Another finding from collaborative evaluation and discussion activities indicated that the participants enjoyed the mentoring program. Result in the training provoked their preparedness to teach. Consequently, they taught the subject more conveniently and flexibly and their students seemed to enjoy their English language class, as they reported. The teachers learned to develop their social competence through giving their students personal attention; they ensured their students progressed. To note, the teachers articulated that the activities in the program were interesting. They confessed to benefit from the evaluation and discussion among the participants and the researchers. Results in these evaluation and discussion became the base line to improve their teaching plan and their upcoming teaching practices. These activities were done repeatedly throughout the mentoring periods.

Apart from the earlier findings, self-evaluation reports showed that the teachers faced different kinds of issues, including self-regulation (e.g., emotion, cognition, behavior, and aspect of context during the teachings). In addition, this report documented the ways they handled the issues. In another part of the report, space to write critical comments on their performance was provided, this part focused on presenting strengths and weaknesses from meeting the goals. As data were collected, they discussed the findings collaboratively in the forum. The critical results of the discussion became constructive inputs to the participants. Being involved in this continuous discussion would encourage the participants to negotiate, share, and discuss a common platform for their professional practices, important for their development (Johannessen, 2015). Eventually, the participants confessed to learn many things from the forums. The mentoring activities as a whole allowed them to combine the puzzles of different knowledge from experiencing direct teaching, evaluation, and discussion. This condition is in line with the claim that educational action research helps the teachers accept confusion and disorientation while evolving a more comprehensive understanding as a researcher and practitioners through observation and field notes (Angelides et al., 2005; Duenkel \& Pratt, 2013; Mcniff \& Whitehead, 2006). Adding the previous comments, some other participants argued this program sharpened their pedagogical vision, and planning and raised their awareness of different ways of handling the pedagogical problems.

Overall, this program had successfully influenced the participants' perceptions towards their current pedagogical environment. Positive dynamic mentoring activities had facilitated the development of mutual trust among the participants (Kiilo \& Kutsar, 2012). Their openness, similarities despite the different teaching environment, mutually broadening insights, realizing helpfulness, and mutual understanding among participants were the convincing evidences. The objectives of the program were achieved due to the participants' active intention and desire to make the changes either within communities or among individuals in particular environments (Dikilitas et al., 2015; Drake, 2014; Jones \& Brader-araje, 2002). The applied concept of the qualitative approach in the study appeared to be helpful to support the program. Most importantly, the participants admitted receiving benefit from working collaboratively as a team. This finding was in line with the notion that collaboration among teachers encourages the development of their professionalism (See: Cordingley, 2015; Dakhiel, 2017; MacPhail et al., 2019). Likewise, the data collection result further informed that the participants learned to value, observe, and reflect on the changes in their attitudes and emotional state within their practices. They also believed to have better awareness on the importance of sustainable professional development. They realized that teaching should be dynamic and so they admitted the mostly favored teaching methods did not guarantee its suitability to the future demand of educational practices (Creswell, 2009).

Although the participants had experienced a promising success of the mentoring program, this still leaves some critical questions: How does the teachers sustain their integrative motivation in the longerterm? and How should the institution behave to continuously support their teachers' development? These questions become important as motivation is inconsistent. Lack of supports from institution has the potential to demotivate teachers from continuously doing TPD, which may eventually endanger the process of education (Zhang et al., 2019).

\section{Conditions contributing to sustainable development as a result in the TPD Program}

Participants' perspectives in their career development were all documented and discussed in the monthly discussion. Successful changes over the mindset, attitude, and integrative motivation were seen as a positive result. The following conditions leading to sustainable development were identified during the mentoring program. First, possible improvement in the institutional setting: a special day for participants to participate in development activities, teaching community to replace the lack of learning environment, dissemination of the 
mentoring program and its result, availability of supports and helps to the participants. Second, possible improvement in the institutional level: to facilitate the teachers' changes in the mindset, integrative motivation, and attitude, to improve the existing model of teacher professional development, to encourage 'productive community of practices' by empowering not only teachers' understanding of the new knowledge but also mutual engagement and commitment to doing things together' (Somekh, 2006), to initiate collaborative activities and to provide recommendations for the institution. Third, practices at individual domain: to promote collaboration among teachers, to enable interpersonal communication needed to create a learning community, and to observe other participants' teaching performance to build tentative understanding, and to examine current understanding of the participants.

The findings informed that the issues on teacher professional development were unique and complex. It is hard to claim that the promising success of TPD practices is only due to a particular factor, rather, some studies reported the result in TPD practices was influenced by multiple factors working together to achieve the same objective of improving teacher professionalism (Steyn, 2005; Wichadee, 2012). The same program of TPD is likely to generate different results when it is applied to the different contexts of practices (Kennedy, 2016; Opfer \& Pedder, 2011). Nonetheless, the teachers' involvement in decision making at a local scale; the follow-up activities, which count in the model of structured knowledge and skill construction (Postholm, 2012); the empowerment of collaboration geared towards learning community to guaranty sustainability and improvement of teacher professionalism; and the implementation of necessary activities involving decision making from the institution, are the factors, which may support better planning for a teacher professional development program.

\section{CONCLUSION}

From the sixth month mentoring program, we conclude that the participants were greatly taking the advantage of the qualitative approach. Seeing the process during the mentoring period and the progress of the mentoring participants, elaborated in the result of observation, interview, and document analyses, we are convinced that the program was proven to be effective. Teachers were experiencing from developments, indicated by: the increasing ability to manage the class while using various teaching strategies and resources; the change in the mindset, and attitude; the improvement of integrative motivation; the higher respect to the social interaction and mutual trust for professional development; the increasing awareness of being professional; and most importantly as this program involved decision- maker, supports were geared towards improving teacher professional qualities. Although this mentoring program was a promising success, we may critically question whether the participants' integrative motivation can sustain their continuous professional development in a longer-term. Therefore, the existing supports and appropriate policies from the institution as well as the other initiatives need to be consistent as they are essential to provoke teachers' continuous development. Finally, we consider the qualitative approach in the present study as an effective concept for teacher professional development.

\section{ACKNOWLEDGEMENTS}

Acknowledgement and gratitude are addressed to Education Fund Management Institution (LPDP), the Ministry of Finance, Republic of Indonesia, and Universitas Islam Sultan Agung as the sponsors of the research project and all parties who have supported the success of the mentoring program based in Indonesia. Without their support, this project would not be here.

\section{REFERENCES}

Alhabahba, M. M., \& Mahfoodh, O. H. A. (2016). The use of the internet for English language teachers' professional development in Arab countries. Australian Journal of Teacher Education, 41(4), 1-9. https://doi.org/10.14221/ajte.2016v41n4.1

Angelides, P., Evangelou, M., \& Leigh, J. (2005). Implementing a collaborative model of action research for teacher development. Educational Action Research, 13(2), 275-290. https://doi.org/10.1080/09650790500200288

Ashton-Hay, S. (2006). Constructivism and powerful learning environments: create your own! 9 th International English Language Teaching Convention. http://eprints.qut.edu.au/17285/1/17285.pdf

Avillanova, A. A., \& Kuswandono, P. (2019). English teacher professional development in Indonesia: The challenges and opportunities. English Review: Journal of English Education, 8(1), 4150. https://doi.org/10.25134/erjee.v8i1.1972

Banegas, D., Pavese, A., Velázquez, A., \& Vélez, S. M. (2013). Teacher professional development through collaborative action research: Impact on foreign English-language teaching and learning. Educational Action Research, 21(2), 185-201. https://doi.org/10.1080/09650792.2013.789717

Bharati, D. A. L. (2010). Teachers' professional development through an observation in immersion classes based on the documents and teaching and learning processes. Language Circle: Journal of Language and Literature, 4(2), 91-101. https://journal.unnes.ac.id/nju/index.php/LC/artic le/view/897

Borg, S., Clifford, I., \& Htut, K. P. (2018). Having an 
EfECT: Professional development for teacher educators in Myanmar. Teaching and Teacher Education, 72, 75-86. https://doi.org/10.1016/j.tate.2018.02.010

Boud, D., \& Hager, P. (2012). Re-thinking continuing professional development through changing metaphors and location in professional practices. Studies in Continuing Education, 34(1), 17-30. https://doi.org/10.1080/0158037x.2011.608656

Canh, L. Van, \& Minh, N. T. T. (2012). Teacher learning within the school context: An ecological perspective. Indonesian Journal of Applied Linguistics, 2(1), 52-67. https://doi.org/10.17509/ijal.v2i1.73

Clardy, A. (2000). Learning on their own: Vocationally oriented self-directed learning projects. Human Resource Development Quarterly, 11(2), 105125. https://doi.org/10.1002/15321096(200022)11:2<105::aid-hrdq2>3.0.co;2-5

Cohen, J., \& Grossman, P. (2016). Respecting complexity in measures of teaching: Keeping students and schools in focus. Teaching and Teacher Education, 55, 308-317. https://doi.org/10.1016/j.tate.2016.01.017

Cordingley, P. (2015). The contribution of research to teachers' professional learning and development. Oxford Review of Education, 41(2), 234-252. https://doi.org/10.1080/03054985.2015.1020105

Creswell, J. W. (2009). Research design: Qualitative, quantitative, and mixed methods approach (3rd Ed.). Sage Publications.

Creswell, J. W. (2012). Educational research (4th Ed.). Pearson.

Dakhiel, M. A. (2017). Factors affecting the quality of English language teaching in preparatory year, University of Jeddah. English Language Teaching, 10(7), 43-60. https://doi.org/10.5539/elt.v10n7p43

Dayoub, R., \& Bashiruddin, A. (2012). Professional development in education exploring English language teachers' professional development in developing countries: Cases from Syria and Pakistan. Professional Development in Education, 38(4), 589-611. https://doi.org/10.1080/19415257.2011.649986

Dikilitas, K., Smith, R., \& Trotman, W. (2015). Teacher-researchers in Action. IATEFL Research Special Interest Group.

Drajati, N. A., Tan, L., Haryati, S., Rochsantiningsih, D., \& Zainnuri, H. (2018). Investigating English language teachers in developing TPACK and multimodal literacy. Indonesian Journal of Applied Linguistics, 7(3), 575-582. https://doi.org/10.17509/ijal.v7i3.9806

Drake, D. H. (2014). Researching prisoner experiences with prison officers: An action research-inspired approach. Action Research, 12(1), 94-109. https://doi.org/10.1177/1476750313516810

Duenkel, N., \& Pratt, J. (2013). Ecological education and action research: A transformative blend for formal and nonformal educators. Action Research, 11(2), 125-141. https://doi.org/10.1177/1476750313477156
Ferhat, Y. (2016). An institutional perspective into professional development of English teachers: A case of schools of foreign languages. Procedia Social and Behavioral Sciences, 232, 828-832. https://doi.org/10.1016/j.sbspro.2016.10.112

Franco-fuenmayor, S. E., Padrón, Y. N., Waxman, H. C., Padrón, \& Waxman, H. C. (2015). Investigating bilingual/ESL teachers' knowledge and professional development opportunities in a large suburban school district in Texas. Bilingual Research Journal, 38(3). https://doi.org/10.1080/15235882.2015.1091049

Galanes, G. J., \& Adams, K. (2019). Effective group discussion: Theory and practice. McGraw-Hill Education.

Girvan, C., Conneely, C., \& Tangney, B. (2016). Extending experiential learning in teacher professional development. Teaching and Teacher Education, 58, 129-139. https://doi.org/10.1016/j.tate.2016.04.009

Gleeson, M., \& Davison, C. (2016). A conflict between experience and professional learning: Subject teachers' beliefs about teaching English language learners. RELC Journal, 47(1), 43-57. https://doi.org/10.1177/0033688216631221

Good, J. (2003). Involving stakeholders in determining professional development center attendance policies. International Journal of Educational Management, 17(1), 14-18. https://doi.org/10.1108/09513540310456356

Hansen-Thomas, H., Dunlap, K., Casey, P. J., \& Starrett, T. (2014). Teacher development: De facto teacher leaders for English language learners. International Journal of Learning, Teaching and Educational Research, 5(1), 35-47. http://mail.ijlter.org/index.php/ijlter/article/view/ 62

Hetherington, L. (2013). Complexity thinking and methodology: The Potential of "complex case study" for educational research. Complicity: An International Journal of Complexity and Education, 10(1/2), 71-85. https://doi.org/10.29173/cmplct20401

Hodgson, Y., Benson, R., \& Brack, C. (2013). Using action research to improve student engagement in a peer-assisted learning programme. Educational Action Research, 21(3), 359-375. https://doi.org/10.1080/09650792.2013.813399

Jensvoll, M. H., \& Lekang, T. (2018). Strengthening professionalism through cooperative learning. Professional Development in Education, 44(4), 466-475. https://doi.org/10.1080/19415257.2017.1376223

Johannessen, Ø. L. (2015). Negotiating and reshaping Christian values and professional identities through action research: Experiential learning and professional development among Christian religious education teachers. Educational Action Research, 23(3), 331-349. https://doi.org/10.1080/09650792.2015.1009141

Jones, M. G., \& Brader-araje, L. (2002). The impact of constructivism on education: Language, discourse, and meaning. American 
Communication Journal, 5(3), 1-10. http://www.academia.edu/download/50935717/jo nes.pdf

Kennedy, A. (2007). Continuing professional development (CPD) policy and the discourse of teacher professionalism in Scotland. Research Papers in Education, 22(1), 95-111. https://doi.org/10.1080/02671520601152128

Kennedy, M. M. (2016). How does professional development improve teaching? Review of Educational Research, 86(4), 945-980. https://doi.org/10.3102/0034654315626800

Kiilo, T., \& Kutsar, D. (2012). Exploring constructivist social learning practices in aiding Russianspeaking teachers to learn Estonian: An action research approach. Educational Action Research, 20(4), 587-604. https://doi.org/10.1080/09650792.2012.727649

Knapp, M. S. (2003). Professional development as a policy pathway. Review of Research in Education, 27(1), 109-157. https://doi.org/10.3102/0091732x027001109

Krueger, R. A. (2002). Designing and conducting focus group interviews. http://www.comm.umn.edu/akoerner/courses/543 1-S10/Krueger-FocusGroupInterviews.pdf

Kwakman, K. (2003). Factors affecting teachers' participation in professional learning activities. Teaching and Teacher Education, 19(2), 149170. https://doi.org/10.1016/S0742051X(02)00101-4

MacPhail, A., Ulvik, M., Guberman, A., Czerniawski, G., Oolbekkink-Marchand, H., \& Bain, Y. (2019). The professional development of higher education-based teacher educators: Needs and realities. Professional Development in Education, 45(5), 848-861. https://doi.org/10.1080/19415257.2018.1529610

Mason, M. (2008a). Complexity theory and the philosophy of education. Educational Philosophy and Theory, 40(1), 4-18. https://doi.org/10.1111/j.14695812.2007.00412.x

Mason, M. (2008b). What is complexity theory and what are its implications for educational change? Educational Philosophy and Theory, 40(1), 3549. https://doi.org/10.1111/j.14695812.2007.00413.x

Mcniff, J., \& Whitehead, J. (2006). All you need to know about action research: An introduction. Sage Publications.

Meyer, J. H. F., \& Land, R. (2005). Threshold concepts and troublesome knowledge (2): Epistemological considerations and a conceptual framework for teaching and learning. Higher Education, 49, 373-388. https://doi.org/10.1007/s10734-0046779-5

Mitchell, D. E., \& Peters, M. J. (1988). A stronger profession through appropriate teacher incentives. Educational Leadership, 46(3), 7478.

http://www.ascd.org/ASCD/pdf/journals/ed_lead/ el_198811_mitchell.pdf
Namunga, N.W., \& Otunga, R. N. (2012). Teacher education as a driver for sustainable development in Kenya. International Journal of Humanities and Social Science, 2(5), 228-234. http://www.ijhssnet.com/journals/Vol_2_No_5_ March_2012/27.pdf

Nelson, M. (2017). Engaging adult learners in professional development environments. Grand Canyon University. https://www.researchgate.net/publication/318349 551

Novozhenina, A., \& López, M. (2018). Impact of a professional development program on EFL teachers' performance. HOW Journal, 25(2), 113-128. https://doi.org/10.19183/how.25.2.406

Nugroho, K. Y., \& Wulandari, D. F. (2017). Constructivist learning paradigm as the basis on learning model development. Journal of Education and Learning, 11(4), 410-415. https://doi.org/10.11591/edulearn.v11i4.6852

Opfer, V. D., \& Pedder, D. (2010). Benefits, status and effectiveness of Continuous Professional Development for teachers in England. Curriculum Journal, 21(4), 413-431. https://doi.org/10.1080/09585176.2010.529651

Opfer, V. D., \& Pedder, D. (2011). Conceptualizing teacher professional learning. Review of Educational Research, 81(3), 376-407. https://doi.org/10.3102/0034654311413609

Packer, M. J., \& Goicoechea, J. (2010). Sociocultural and constructivist theories of learning: Ontology, not just epistemology. Educational Psychologist, 35(4), 227241. https://doi.org/10.1207/S15326985EP3504_ 02

Park, M., \& So, K. (2014). Opportunities and challenges for teacher professional development: A case of collaborative learning community in South Korea. International Education Studies, 7(7), 96-108. https://doi.org/10.5539/ies.v7n7p96

Perkins, D. (1999). The many faces of constructivism. Educational Leadership, 57(3), 6-11. https://eric.ed.gov/?id=EJ597073

Postholm, M. B. (2012). Teachers' professional development: A theoretical review. Educational Research, 54(4), 405-429. https://doi.org/10.1080/00131881.2012.734725

Purdon, A. (2004). Perceptions of the educational elite on the purpose of a national framework of continuing professional development (CPD) for teachers in Scotland. Journal of Education for Teaching, 30(2), 131-149. https://doi.org/10.1080/0260747042000229753

Putnam, R. T., \& Borko, H. (2000). What do new views of knowledge and thinking have to say about research on teacher learning? Educational Researcher, 29(1), 4-15. https://doi.org/10.3102/0013189X029001004

Rahman, A. (2016). Teacher professional development in Indonesia: The influences of learning activities, teacher characteristics and school conditions [Doctoral dissertation]. University of Wollongong. https://ro.uow.edu.au/theses/4721/ 
Richards, J. C. (1990). Towards reflective teaching. The Teacher Trainer, June, 1. https://www.researchgate.net/publication/265934 213_Towards_Reflective_Teaching

Richards, J. C., \& Schmidt, R. (2010). Longman: Dictionary of language teaching \& applied linguistics (4th Ed.). Pearson Education Limited.

Roux, R., \& Valladares, J. L. M. (2014). Professional development of Mexican secondary EFL teachers: Views and willingness to engage in classroom research. English Language Teaching, 7(9), 21-27. https://doi.org/10.5539/elt.v7n9p21

Somekh, B. (2006). Action research: A methodology for change and development. Open University Press.

Steyn, G. M. (2005). Exploring factors that influence the effective implementation of professional development programmes on invitational education. Journal of Invitational Theory and Practice, 11, 7-34. https://eric.ed.gov/?id=EJ728851

Strategic Research. (n.d.). Classroom Observation Form (pp. 4-6). http://www.edec.org/Resources/DI/DITeacherEval.pdf

Sulistiyo, U. (2015). Improving English as a foreign language teacher education in Indonesia: The case of Jambi University [Unpublished doctoral thesis]. RMIT University.

https://researchbank.rmit.edu.au/eserv/rmit:16152 1/Sulistiyo.pdf

Tanang, H., \& Abu, B. (2014). Teacher professionalism and professional development practices in South Sulawesi, Indonesia. Journal of Curriculum and Teaching, 3(2), 25-42. https://doi.org/10.5430/jct.v3n2p25

Thornton, K., \& Cherrington, S. (2019). Professional learning communities in early childhood education: A vehicle for professional growth. Professional Development in Education, 45(3), 418-432. https://doi.org/10.1080/19415257.2018.1529609

Tigert, J. M., Kidwell, T., Budde, C. M., Guzman, N. L., Lawyer, M., \& Peercy, M. M. (2018). "It took my knowledge to the limits": The edTPA teacher performance assessment and its implications for TESOL. Teacher Learning and Professional Development, 3(1), 19-38. https://journals.sfu.ca/tlpd/index.php/tlpd/article/ view/45

Wardoyo, C., Herdiani, A., \& Sulikah, S. (2017). Teacher professionalism: Analysis of professionalism phases. International Education Studies, 10(4), 90-100. https://doi.org/10.5539/ies.v10n4p90

Wichadee, S. (2012). Factors related to professional development of English language university teachers in Thailand. Journal of Education for Teaching: International Research and Pedagogy, 38(5), 615-627. https://doi.org/10.1080/02607476.2013.739795

Wildemuth, B. M., \& Perryman, C. L. (2009). Discourse analysis. In B. M. Wildemuth (Ed.), Applications of Social research methods to questions in information and library science (pp. 320-328). Libraries Unlimited. https://doi.org/10.1075/hop.11.thi1

Yazan, B., \& Peercy, M. M. (2018). "Pedagogically speaking, I'm doing the right things": Three preservice ESOL teachers' identity formation. Teacher Learning and Professional Development, 3(1), 1-18. https://journals.sfu.ca/tlpd/index.php/tlpd/article/ view/47

Yuwono, G., I. \& Harbon, L. (2010). English teacher professionalism and professional development: Some common issues in Indonesia. Asian EFL Journal, 12(3), 145-163. https://asianefljournal.com/PDF/September2010.pdf\#page $=145$

Zein, M. S. (2016). Government-based training agencies and the professional development of Indonesian teachers of English for young learners: Perspectives from complexity theory. Journal of Education for Teaching, 42(2), 205 223. https://doi.org/10.1080/02607476.2016.1143145

Zhang, S., Shi, Q., \& Lin, E. (2019). Professional development needs, support, and barriers: TALIS US new and veteran teachers' perspectives. Professional Development in Education, 46(3), 440-453. https://doi.org/10.1080/19415257.2019.1614967

Zuber-skerritt, O., \& Roche, V. (2014). A constructivist model for evaluating postgraduate supervision: A case study. Quality Assurance in Education, 12(2), 82-93. https://doi.org/10.1108/09684880410536459 